\title{
Adolescents' Attitude Towards Premarital Sex
}

\author{
Ifeoma R. Eze (mrs.) \\ HOD: Department of Teacher Education \& Development \\ BA ISAGO University College. Botswana \\ Email: Ifeoma.eze@baisago.co.bw
}

\section{Doi:10.5901/mjss.2014.v5n10p491}

\section{Abstract}

The study was on the adolescents' attitude towards premarital sex in Awka North and South Local Government Areas of Anambra State. The general purpose of study was identifying some of the attitudes of adolescents towards premarital sex, the major factors responsible for the attitudes of those adolescents towards premarital sex. And then suggest counselling techniques that will help in controlling the adolescent premarital sex. Two research questions and two hypotheses were formulated the instrument used for data collection was questionnaire for the adolescents attitude towards premarital sex (AATPSQ). The statistical analyses used were mean and standard deviation for the research questions and t-test for the hypotheses. The findings of the study reveal that: Adolescents have not less than 20 permissive attitudes towards premarital sex and the views of the adolescents and adults parents on the adolescents' attitude towards premarital sex do not differ significantly. It was recommended among others that the Guidance Counsellors in Counselling Association of Nigeria should work hard to create awareness through pastoral and group counselling to re-orientate the members of the society on the issues and problems of sex.

\section{Introduction}

\subsection{Background of the Study}

Human beings are a class of primates, who are known as "Homo-Sapiens", meaning "the modern man" or the wise man with the highest brain capacity $(1700 \mathrm{cc}$ ) among all creatures. That is why human beings are the most civilised of all living things on earth (Oyalinka, 1972)

In contrast to other primates, human sexual behaviour is strongly determined by cultural and social influences. All societies have to place some degree of regulation upon impulse control.

In the traditional Nigerian society, sex outside marriage was seen as repugnant and forbidden, and people were not expressing their opinions and views on love, sex and marriage openly. Ukachi (1980:14) emphasized that "the ancient African was far from being an abode of laissez-faire morality. There were strict moral principles that determined code of conduct. Established moral code guided individual members on the social behaviours". Moreover it was a feature for both the bride and the groom to be ignorant about sexual act until their marriage night. Such was the practice of most Nigerian communities. Also social punishments like songs of contempt and degradation meted out at marriage, to brides that lost their virginity before the marriage night, made most girls refrain from premarital sex experiences. They strove to maintain the good name of their families (Eze, 1989).

Furthermore, the advent of Christianity also strengthened the restrictive attitude towards premarital sexual expressions. Schools were built and managed by missionaries and very stringent codes of conduct were imposed on heterosexual activities. They aimed at preventing children from any type of sexual activity, which was regarded as an act of immorality and sin against God.

In the recent past, the western societies such as Europe and America underwent a radical change in their attitude towards sex. According to Ehrman (1959), the weight of evidence from social attitude and behaviours among the Western adults and youths. This sexual revolution, as the trend is often called, is in fact, one of the most striking features of Western sociocultural milieu today.

Also as a result of this sexual revolution in the Western world, sex became glorified and commercialised, and all types of behaviours such as nudity, homosexuality, premarital sex and the likes were being experimented on. In some cases, even legalised pornographic magazines, novels and a large number of books have been published. According to Armstrong, (1972:16) "we live in a crazy world". 
Onyemelukwe (1993) explained that in contemporary time, Nigerian youths have joined in the sex revolution in Europe and America. The impact of alien ideas and cultures, mass communication and conditions of urban life on the behaviour and attitude of Nigerian adolescents cannot be over emphasized. There has been extensive interest, inquiry and curiosity in premarital sexual activities. The adolescents are exposed to sexual stimuli in magazines, television and the movies to a greater extent than before, thereby creating a general trend towards liberated attitude and values that encourage open discussion on sexuality, once considered a taboo.

Researchers like Reiss (1964), master and Johnson (1966) and Bell and Chakes (1970) agreed that the opinions and attitudes of the present day youths towards sex are becoming more liberal and permissive, and this is as a result of permissive environment in the society.

In addition, it has been asserted that the rate of premarital sexual occurrence in our society is very high (Roche, 1986 and Clayton and Bokemeier, 1980). This attitude according to them is in continuous increase and they believe that many youths who have not engaged in coitus at the time of their study may do so before they marry.

According to Mahoney (1978), and Bell and Coughey (1980), it is obvious today that there is dramatic liberalization in premarital sexual attitude. Owuamanam (1983), in his contribution opined that adolescents' kissing, embracing, breast fondling and sexual intercourse attitude were found to be significantly associated with adolescents' type of orientation.

Commenting on this, Onyemelukwe (1993) indicated that peer-orientated adolescents differ significantly from parent-oriented in their degree of indulgence in these sexual activities. Also Akinboye (1987) pointed to peer influence when he stated that there is always the tendency for adolescents to want to be like his/her peer who are seen having friends of the opposite sex. Hence social forces may be operating to compound the problem of adolescents.

Furthermore, researchers, after meditating on the rate of the increase in incidence of premarital sex, observed reasons which seem to predispose to increased sexuality particularly among young youths: Anate (1986) emphasized that increasing urbanization is very influential to premarital permissiveness. This confirmed the observation made by Udoh (1981:21) "hundreds of Nigerian teenage girls roam the streets of urban centres, offering themselves to various men for economic gain".

Jones (1970), after a series of studies revealing a decrease in commitment to religion since the 1950s, concluded that greater percentage of youths are not likely to turn their minds increasingly towards religion for personal help for them to improve immediate conditions about them. Hurlock as quoted in Agbaje (1991) says that "the adolescent needs Religion and not ideology of he believes that it is religion that can give him faith in life and a feeling of security". He further stated that the adolescent could not get it from authoritative dogmas as sentiments. He needs a religion that is dissociated from everyday life and that looks down upon the pleasures of youth.

Recent studies have shown that whereas the Western world like Europe and America have long realised the importance of sex education and are using it in containing and channelling the sex revolution in the best possible direction, we have left our adolescents unguided. As a result of inadequate information on sex-related problems such as unintended pregnancies, dumping of unwanted babies and illegal abortions.

Two teenage girls commented, Serifatu Kassim is 15 years old said that she disappointed her struggling mother "I got pregnant few months to my school certificate examination and was expelled from school". Also Titi Philips 16 years old, now a street trader got her dream of being an accountant shattered in form three (Eze, 1994:24)

Based on the afore mentioned problems encountered by the adolescents who indulge in premarital sex, there is need for a work of this nature to be carried out on the adolescents' attitude towards premarital sex in Awka North and South Local Government Areas, so as to be able to suggest appropriate counselling technique for modifying any identified undesirable attitude

\subsection{Statement of the Problem}

Researchers have observed that there is prevalence of premarital sexual practices among adolescents, the teenagers in contemporary society, which leads to high incidence of teenage pregnancies and sexually transmitted diseases. Most writers and school authorities frown upon adolescents' indulgence in premarital sex. Some communities carry out disciplinary action on youths who indulge in it. The Federal Health Management Board engages in series of campaigns to create public awareness on the danger and circulation of sexually transmitted diseases. But in this study, literature is lacking on the attitude of adolescents towards premarital sex. Given the amount of public concern for the consequences of apparent adolescents indulgence in premarital sex, finding out the adolescents' attitude will provide the necessary information for planning useful intervention programmes aimed at solving the problems arising from seemingly adolescent' premarital sexual practices. 


\subsection{Research Questions}

The following research questions were formulated to guide the researcher in the study.

1. What are the adolescent attitudes towards premarital sex?

2. What are the factors influence adolescents attitudes towards premarital sex?

\subsection{Research Hypotheses}

Two null hypotheses have been formulated to help the researcher in the study and tested at $0.05 \%$ level of significance.

1. Gender has no significant influence on the adolescents' attitudes towards premarital sex.

2. Gender has no significant influence on the adolescents' views on the factors that influence their attitudes towards premarital sex.

\section{Literature Review}

\subsection{Incidence of Premarital Sexual Permissiveness}

In the past, Nigerians approach sexual behaviour with great respect. There was cultural prohibition of premarital sexual experimentation, but it has been observed that adolescents no longer adhere to the cultural regulations regarding sex.

According to Bell and Chaskes (1970), Kaats and Davis (1970), Mosher and Cross (1971), the attitudes of modern youths towards premarital sexual activities have become more liberal and permissive than what it was in the past. Hence Meyerson, (1975) stated that adolescents sexuality reveals a moving kaleidoscope of colourful feelings and changes that can be exciting and frightening, pleasurable and painful, joyous and sad, loving and hating.

Speaking on the above observation, Conger (1961:52) stated that "of all the developmental events of adolescence, the most dramatic is the increase in sexual drive and the new and often mysterious feelings and thoughts that accompany it". As a result of the adolescents' dramatic liberalization in premarital sexual attitudes, Wagner (1980) was highly worried when he compared it with the standard behaviour. Also Okieh (1981) complained that virginity as an aspect of growing up is now something indulged in indiscriminately.

I another occasion, Armstrong (1981) expressing his views emphasized that, the premarital love-making which is now rampant among the adolescents today in form of necking, petting and sexual intercourse are governed by "private love", that is carnal love and not God's kind of love, (Agape love). It is just a mere sensual gratification.

Again, Zelnik, Kanter and Ford (1981) noted that there is now a liberal attitude towards premarital sex among the teenagers and that this is in a very high increase. This they observed is global. The situation is not different in Nigeria because according to Salami (1981) and Lantunji (1981), the Nigerian society is so saturated with moral laxities that premarital sex is common at all levels of our school system. Amazingly, they noted also that adolescents of pubertal stage in primary schools indulge in too. This attitude of the present day youths towards premarital sex has become more widespread for almost all age groups (Phpps-Yonas, 1980).

Onwuamanam (1988:11) in a write up said that "the traditional values among Nigerians for sanctity of sex and sex for sexual attitudes. He went further to say that, the present time can be described as a period of "sex explosion" in which youths are enjoying unprecedented sex and sexual permissiveness. He also noted that there is evidence of high rate of high rate of coital sex and premarital sexual involvement among Nigerian adolescents (Onwuamanam 1983)

Agbaje (1991) as quoted from Atkinson, Atkinson and Hilgard 'study on adolescents' sexual standard and behaviour' found that the last twenty years have witnessed an almost revolutionary change in attitudes towards sexual activity. They went further to say that in surveys regarding premarital sex, homosexuality, extra-marital sex and specific sexual acts are probably more open and permissive today than they have at any time in recent history.

Also they concluded that, young people are exposed to sexual stimuli in magazines, televisions and the movies to a greater extent than before, satisfactory birth control methods and availability of abortions and condoms have lessened the fear of pregnancy. All of these changes give the newly matured individual more freedom today. They have more permissive attitude towards sexual intercourse, and this has been accompanied by changes in actual behaviour.

The World Health Organization (WHO) in its Chronicles 18, 451 (1964) and 19, 7(1965) made known to the world the rise in the incidence and existence of sexually transmitted diseases (STD). This was confirmed by more sexually transmitted diseases being discovered and reported in the society in general. Webster (1972) reported that the incidence of infection of (STD) has risen to and epidemic proportion. In addition, the medical committee of FIFA, in THIS DAY, vol. 1, No 9, June 29, (1995) warned participating countries in U-17 world championship for the FIFA/JVC cup in Ecuador, to 
beware of the dreaded Acquired Immune-Deficiency Syndrome (AIDS). The commonest in our society are Acquired Immune-Deficiency Syndrome (AIDS), Non-specific genital infection (NSGI), Candidiasis, Gonorrhoea, Syphilis, Herpes genitals, Genital warts, Trichomoniasis, Scabies, Cancroid and Venerohpobia.

Meanwhile, Morton (1971) opined that the commonest factor for the spread of venereal diseases (VD) is the frequency of sexual contact and the increase in sexual freedom. The unfortunate thing in the adolescents' indulgence in premarital sexual practices is that they are not properly guided too.

Onyemelukwe (1993) commenting on this situation said that there is a public outcry against premarital sex even in our urban centres where the general attitude towards it is undoubtedly more permissive. This observation confirmed that made by Hoffman (1984) and Oransaye and Odiase (1983) who noted that the rate of sexual activity among unmarried adolescents in urban areas is on the increase although it is believed that the situation seems to exist in alarming rate in the rural areas where it is becoming a tradition (Izundu, 1991).

As this problem has become a topical issue, the question now is' "What is the cause of this social misconduct"? According to Reiss (1967), he opined that much of the changes in the sexual behaviour of young people are as a result of the growing power of the youths to run their own lives without interference by parents, schools, churches and the law. Also, he observed that findings have shown that high rates of sexual permissiveness tend to be associated with lack of church attendance, identification with peers rather than parents, personal values and the frequent use of illicit drugs or alcohol.

Owuamanam (1962) expressed that the modern adolescents' less constrained attitude towards sexuality could also be attributed to the changing attitude of the attitude of the adult society towards extra-marital sexual relationships. Moreover, parents have been accused of being indifferent to the moral decadence of their children and failing to enforce the cultural moral code, possibly because of their own moral decadence (Eze, 1989). Speaking on this point, Noor, Peterson and Furtensburg (1986) emphasized that the current parental attitude to sexuality leads to the higher incidence of premarital sexual activity. This permissive situation also includes the parents' attitude to sex outside their marital homes.

The family also plays an interesting role in sexual socialization because it is within the social context of the family that one's earliest socialization, sexual and otherwise occurs. Udry (1987) supported this when they stated that the presence of two parents in the family might provide more control than the presence of only one. It may be difficult to escape the surveillance of four watchful eyes than two also two parents will be very difficult to argue down.

On the other hand Udoh (1981) see the delay of marriage due to long period spent in attaining a career, profession and academic qualification by the female as the cause of high incidence of adolescents' crazy attitude towards premarital sex. In earlier centuries, girls marry at puberty and the function of wife hood and mother hood provided biological expression for her sexuality (Eze, 1989).

It is therefore obvious that the sexual attitudes and opinions of present day youths appear to be tending towards being liberal and permissive. However, Medora and Woodwards (1982) observed that none of the boys or girls who were involved in it received any formal sex education. This exposure without corresponding availability of satisfactory knowledge and guidance are deemed to be leading towards heightened incidence of premarital sex and its related problems.

\subsection{Dangers of Premarital Sexual Permissiveness}

The consequences of premarital sex are highly dreadful. According to Omoegun (1995), if there is one important are where the adolescents' reactions to their problems can be terribly marked, it is on the dangers and consequences inherent in premarital sexual activities. Once the adolescent decides to have sex before marriage, a number of consequences which are not pleasant await him or her.

Experts in both medical and education fields have been very concerned about this problem, hence few months ago (September, 1996) the Nigerian Medical Association (NMA) organised a workshop on "Adolescents reproductive health problems in Africa" at Getaway Hotel, Sango Ota, Ogun State. The further confirm the extent of the consequences of adolescent premarital sex, Dr. Evarist Njelesany the W.H.O. representative in Nigeria who was invited to the workshop disclosed that the W.H.O. has designed a family and Reproductive Health programme to support countries in creating and sustaining health promoting conditions at all stages of life. 


\section{Research Methodology}

\subsection{Research Design}

The design of this study was survey type because the research sought information on incidence and attitude of the respondents. As a survey, it studied a chosen sample from the population to discover the relative incidence and attitude of social and psychological variables of the individual (Kerlinger 1977:410). According to Osuala (1987), survey research studies both large and small population to discover the relative incidence, distribution and inter-relations of sociological and psychological variables.

\subsection{Population for the Study}

The population of the study consisted of all adolescents and parents who would be represented by married teachers in Awka North and South Local Government Areas. For the researcher to be able to get appropriated information, the adolescents and the married teachers in all secondary schools in the area of study was used as the target population of the study.

\subsection{Sample and Sampling Technique}

The sampling for the study comprised 430 SS II Students (150 boys and 280 girls) based on proportionate stratified sampling. There are 16 secondary schools in the area of study comprising 5 males, 6 females and 5 co-educational schools with the required level of SS II students needed for this study.

For the selection of the students, simple random sampling technique was employed in selecting 3 boys, 4 girls and 3 co-educational schools making up to 10 schools out of the 16 schools.

Due to the disparity in the number of male and female students in the secondary schools, 25 male students in SS II from each of the 3 boys and 3 co-educational schools selected for the study were used. While 40 female students of SS II in the 4 girls and 3 co-educational schools selected were used.

\subsection{Instrument for Data Collection}

The data gathering instrument for this study was an adapted and modified form of Adolescents' Attitude towards Premarital Sex Questionnaire (AATPSQ) developed by Nwankwo (1997).

\subsection{Standardization of Instrument}

Pilot study was used to refine the instrument (AATPSQ). Then face validity method was also employed and Cronbach Alpha was used for the standardization of the reliability test.

\subsection{Validation of the Instrument}

To determine the suitability and content validity of the instrument, it was presented to specialists in Guidance and Counselling, Psychology, Measurement and Evaluation and Research Methodology, Nnamdi Azikiwe University, Awka. Based on these assessments of these experts, the researcher made some modifications that enhanced the content of the instrument. The items they rejected were either removed considered inadequate or reconstructed into the instrument.

\subsection{Reliability}

The instrument was pilot tested using 50 students and 20 married teachers to attest to the reliability co-efficient of the instrument. Data collected were analysed using Cronbach Alpha () to obtain the internal consistency.

(2) $t-E t$

$$
n-1+2
$$

After the analysis, the co-efficient alpha stood at 0.79 and 0.81 which the researcher considered well enough for the internal consistency and reliability of the instruments 


\subsection{Method of Data Collection}

Copies of the questionnaire were administered by the researcher on the selected students and adult parents. This was to endure proper explanation of the instrument to the respondents and to be able to have a good return of the questionnaires.

\subsection{Method of Data Analysis}

For the data analysis, mean and standard deviation were used in providing answers to the research questions. A mean 3.0 was used as a cut off point for the items for acceptability. Then $z$ and t-test statistics were used to test the null hypotheses formulated for the study. When wither the calculated " $t$ " or " $z$ " values is greater than the critical value " $\mathrm{t}$ " or " $\mathrm{z}$ " value, the null hypothesis is rejected. But when any of the calculated " $t$ " or " $z$ " value is less than the critical value of $t$ or $z$ the null hypothesis is accepted (Nworgu, 1991)

\section{Results and Data Analysis}

\subsection{Research Question I: What are the adolescent attitudes towards premarital sex?}

Table I: Adolescents' Response on Their Attitudes towards Premarital Sex

\begin{tabular}{|c|l|c|c|c|c|}
\hline \multirow{2}{*}{ S/No. } & \multicolumn{1}{|c|}{ ITEMS } & \multicolumn{2}{|c|}{ Males } & \multicolumn{2}{c|}{ Females } \\
\cline { 3 - 5 } & & $\bar{x}$ & Sd & $\bar{x}$ & Sd \\
\hline 1 & I like engaging in premarital sex & 3.54 & 1.25 & 3.55 & 1.21 \\
\hline 2 & I like to have sexual relations before marriage & 3.54 & 1.31 & 3.79 & 1.14 \\
\hline 3 & I desire breast fondling & 3.66 & 1.36 & 3.63 & 1.18 \\
\hline 4 & I enjoy sex plays & 3.83 & 1.38 & 3.65 & 1.18 \\
\hline 5 & I desire oral-genital sex & 3.35 & 1.38 & 3.09 & 1.27 \\
\hline 6 & I like using pornographic materials & 3.49 & 1.43 & 3.44 & 1.12 \\
\hline 7 & I like having intimate kissing & 3.6 & 1.41 & 3.51 & 1.23 \\
\hline 8 & I cherish casual kissing & 3.6 & 1.14 & 3.43 & 1.27 \\
\hline 9 & I like touching massage & 3.47 & 1.28 & 3.33 & 1.22 \\
\hline 10 & I cherish petting without affection before marriage & 3.33 & 1.23 & 3.2 & 1.23 \\
\hline 11 & I cherish coitus without affection before marriage & 2.52 & 1.46 & 3.08 & 1.2 \\
\hline 12 & I like prostitution as a business & 3.31 & 1.36 & 2.2 & 1.29 \\
\hline 13 & I enjoy petting with little affection before marriage & 3.38 & 1.34 & 3.22 & 1.23 \\
\hline 14 & I enjoy coitus with little affection before marriage & 3.51 & 1.34 & 3.18 & 1.19 \\
\hline 15 & There is nothing wrong with premarital sexual intercourse & 3.16 & 1.38 & 3.24 & 1.2 \\
\hline 16 & Nothing is wrong with a boy who has had sexual intercourse with many girls & 3.2 & 1.32 & 2.97 & 1.25 \\
\hline 17 & Nothing is wrong with a girl who has had sexual intercourse with many boys & 3.53 & 1.3 & 3 & 1.25 \\
\hline 18 & Nothing is wrong with serious necking before marriage & 3.6 & 1.3 & 3.33 & 1.26 \\
\hline 19 & Sexual intercourse before marriage without emotional attachment is good & 3.45 & 1.33 & 3.34 & 1.19 \\
\hline 20 & Nothing is wrong with receptive anal intercourse & 3.37 & 1.44 & 3.27 & 1.3 \\
\hline 21 & Nothing is wrong with inserted anal intercourse & 3.85 & 1.37 & 3.18 & 1.25 \\
\hline
\end{tabular}

The above Table I show that the male adolescents accepted that they have at least 20 out of 21 permissive attitudes towards premarital sex. While their female counterparts indicated that they have 19 out of the 21 permissive attitudes towards premarital sex.

Also shown in the Table was that the males say not to cherishing coitus without affection before marriage, the female group on the other hand rejected liking prostitution as a business also the statement that nothing is wrong with a boy who has had sexual intercourse with many girls was rejected.

This is because they have means that are below the acceptance point of 3.0 and therefore were regarded as not acceptable. 


\subsection{Research Question 2: What are the factors influence adolescents' attitudes towards premarital sex?}

Table 2: Adolescents' Responses on the Factors Influencing Their Attitudes towards Premarital Sex

\begin{tabular}{|c|c|c|c|c|c|}
\hline \multirow{2}{*}{ S/No. } & \multirow{2}{*}{ ITEMS } & \multicolumn{2}{|c|}{ Males } & \multicolumn{2}{|c|}{ Females } \\
\hline & & $\bar{x}$ & Sd & $\bar{x}$ & Sd \\
\hline 1 & To practice what they learn from their friends & 3.91 & 1.35 & 3.71 & 1.29 \\
\hline 2 & To practice what they learn from their parents & 4.43 & 1.37 & 3.8 & 1.36 \\
\hline 3 & To show maturity & 3.15 & 1.39 & 3.74 & 1.3 \\
\hline 4 & To boost their ego & 3.42 & 1.43 & 3.4 & 1.41 \\
\hline 5 & To derive happiness & 3.47 & 1.4 & 3.5 & 1.33 \\
\hline 6 & For sexual gratification & 3.29 & 1.36 & 3.37 & 1.26 \\
\hline 7 & For material gratification & 3.39 & 1.2 & 3.54 & 1.23 \\
\hline 8 & To satisfy their sexual ego & 3.19 & 1.34 & 3.21 & 1.36 \\
\hline 9 & To show off & 3.16 & 1.39 & 3.31 & 1.27 \\
\hline 10 & To challenge their parents & 3.29 & 1.37 & 3.4 & 1.26 \\
\hline
\end{tabular}

Table 2 above reveals that both the male and female adolescents identified not less than 10 factors influencing their attitudes towards premarital sex. This is because the 10 factors have not less than the mean scores of 3.0. The factors range from practising what they learn from their friend, show their maturity, boosting their ego, to challenging their parents among others.

\subsection{Null Hypothesis I}

Gender has no significant influence on the adolescents' attitudes towards premarital sex.

Table 3: Comparison of Adolescents' View Based On Gender on Adolescents' Premarital Sexual Attitudes

\begin{tabular}{|c|c|c|c|c|c|c|c|}
\hline Gender & No of Subjects & $\overline{\boldsymbol{x}}$ & Sd & Df & Cal z & Crit z & P.05 \\
\hline Male & 150 & 3.44 & 1.35 & & & & \\
\hline & & & & 428 & 1.308 & 1.645 & (NS) \\
\hline Female & 280 & 3.27 & 1.23 & & & & \\
\hline
\end{tabular}

Table 3 above reveals that at 5 percent level of significance and 428 degree of freedom, the calculated z-test 1.308 is less than the critical z 1.645 on the adolescents, attitude towards premarital sex. This implies that there is no significant difference between the male and female adolescents' views as tested above.

Therefore the null hypothesis of gender has no significant influence on the adolescents' attitude towards premarital sex is accepted.

\subsection{Null Hypothesis 2}

Gender has no significant influence on the adolescent views on the factors that influence their attitudes towards premarital sex.

Table 4: Comparison of Male and Female Adolescents' Responses on the Factors Influencing Adolescents' Attitudes towards Premarital Sex.

\begin{tabular}{|c|c|c|c|c|c|c|c|}
\hline Gender & No of Subjects & $\overline{\boldsymbol{x}}$ & Sd & Df & Cal z & Crit z & P.05 \\
\hline Male & 150 & 3.37 & 1.35 & & & & \\
\hline & & & & 428 & 1.106 & 1.645 & (NS) \\
\hline Female & 280 & 3.52 & 1.31 & & & & \\
\hline
\end{tabular}

The Table 4 above indicates that at 5 percent level of significance and 428 degree of freedom, the calculated z 1.106 is less than the critical z 1.645 on the male and female adolescent views on the factors influencing their attitudes towards 
premarital sex. That is to say that there is no significant difference between the male and female adolescent responses. Therefore, the second null hypothesis is accepted.

\section{Discussion of Findings}

From the answer to research questions 1 , which sought to find the actual permissive attitudes of the adolescents towards premarital sex, it was discovered that they have not less than 20 different permissive attitudes towards premarital sex. They range from kissing, petting without affection to actual sexual intercourse or coitus. The above findings are in line with what researches like Reiss (1964) and Bell and Chaskes 1970 said long ago that the attitude of the present day youths towards sex are becoming more liberal and permissive. Also Roche (1986) warned that the adolescents of those days were more interested in sexual intercourse. Although these authors and researchers above were from Europe and America, and reported their findings in their continents, the situation has been proved to be the same in Nigeria by the findings of the present study. However, Salami (1981) and Latunji (1981) have been stressing that the Nigerian society is so saturated with moral laxities that premarital sex is common at all levels of our school system.

Due to the high rate of sexual permissiveness among our adolescents as discovered in this study, the rate of its twin sister abortion and venereal disease will be very high because it is premarital and unprotected (Niyi 1992 and Omoegun, 1995). The findings of this study showed the reasons why the reported cases of sexual adolescents suffering from AIDS problem in various hospital in Nigeria as reported by Onyemelukwe (1991). Also when asked of the factors influencing their attitudes towards premarital sex adolescents identified at least 10 factors as shown in Table 2. These range from practising what they learn from friends, to challenging their parents.

These observations were pointers to the fact that we are in sex crazy society. As the adolescents disclosed that they learnt their attitudes towards premarital sex from their parents, the male adults confirmed that. This presents findings, therefore, agrees with the findings of Moore, Peterson and Furstenburg (1986) that the current parental attitudes to sexuality led to the higher incidence of premarital sexual activity of the adolescents it is also evidence that parents have failed in their roles of enforcing moral codes towards their children as observed by Eze (1989).

The other factors which are to satisfy their sexual urges, derive sexual gratification, happiness and to stamp their maturity could be due to what Conger (1979) observed. He said that of all the development events of adolescents' the most dramatic is the increase in sexual drive and new often mysterious feeling and thoughts that accompany it.

The findings in Tables 3 and 4 revealed that gender has significant influence on the adolescents' attitude towards premarital sex. This corresponds with the findings of Medora and Surton (1979) who observed that the rate of permissiveness differs in males and females. They however observed that the attitudes and actual indulgence of the males in premarital sex are higher than those of the females.

\section{Conclusion}

From the above discussion, the following conclusion could be safely made.

a) Adolescents have various permissive attitudes towards premarital sex.

b) Many factors influence the adolescents' attitudes towards premarital sex, such as showing off, satisfying sexual urges and the likes.

c) Male and female students have almost the same rate of permissive attitude towards premarital sex but males are more permissive.

\section{Recommendations}

Based on the findings and the implications of the findings of this study, the following recommendations were made:

1. The State Education Commission should work in collaboration with the curriculum designers in the secondary school education to plan how best the adolescents in secondary schools could be helped on sex and sexrelated matters through the knowledge of adolescents' reproductive health.

2. The Guidance Counsellors in Counselling Association of Nigeria should work hard to create awareness through pastoral and group counselling to re-orientate the members of the society on the issues and problems of sex.

3. The Guidance Counsellor and the Social Worker should look for emergency strategies by which the attitudes of the adolescents and even the adult members in the society towards premarital sex can best be changes or amended. 
4. The Federal Government of Nigeria and the State Government should promulgate a decree and enact an edict banning the importation and use of pornographic materials, contraceptives and condoms to reduce the ill information pattern on sex to adolescents and adults in the society.

\section{References}

Agbaje, N.O. (1991). "The adolescents and sex related problems: Implications for the school counsellor" Unpublished. M.Ed. Thesis. University of Lagos. Akinboye, J. (1987). Guidance and Counselling Strategies for handling adolescents and youths problems. Ibadan, University Press Ltd.

Anate, M. (1986). "Illegal Abortion in llorin" The Nigerian Medical Association. 11 (2): 41 - 44.

Armstrong, G.T. (1972). Your Marriage can be Happy. California: Ambassador College Press. Armstrong, H.W. (1981). The Missing Dimension in Sex. USA: World Wide Church of God.

Bell, R.R. and Chaskes, J.B. (1970), "Premarital Sexual Experience among coeds in 1958 and 1968". Journal of Marriage and the Family. 32,81 - 84. Bell, R. and Courgey, K. (1980), "Premarital Sexual Experience among College Females. 1958, 1968 and 1978". Family Relations. 29. 353 - 357.

Clayton, R.R. and Bokenmeier, J.L. (1980). "Premarital Sex in the Seventies". Journal of Marriage and the Family. Nov. 759 - 775

Conger, J. (1961). Adolescence and Youth (2nd Ed) New York: Harper and Row.

Ehrman, (1959), "Sex Education Today". Journal and Moral Education 4315 - 318

Eze, I.R. (1989). "Teenage Pregnancy". Unpublished M. Ed. Thesis. University of Benin.

Eze, I.R. (1994). "Sexuality, Contraceptives and Pregnancy in Nigeria Set Up". Unpublished. M. Ed Term Paper. Nnamdi Azikiwe University, Awka 25 - 26. Hoffman, A.D. (1984). "Contraception in Adolescence, a Review. Psychological aspects". Bulletin of the WHO 62 (1) 153.

Izundu, N.T.A. (1991). Contemporary Issues that Bother on Nigerian Adolescents and Youths. Implications for Counselling in Guidance and Counselling: A Realistic Approach. (Ed) Unachukwu, G.C. and Igborgbor G.C. Owerri: International University Press.

Jones, V. (1970). "Attitudes of College Students and their Charges" A 37 Year Study. Genetic Psychology Monographs Pg. 813.

Kaats, C.R. and Davis, K.E. (1970). "The Dynamics of Sexual Behaviour of College Students". Journal of Marriage and Family. 32, 390 - 399.

Kerlinger, F.N. (1977). Foundations of behavioural Research ( $2^{\text {nd }}$ Ed) New York. Holt, Rinehart and Winston Inc.

Latunii, J.O. (1982). "Sexual Education not Abortion". Daily Sketch

Mahoney, E.R. (1978. Gender of Social Class Differences in Change's in Attitude Towards premarital Coitus". Sociological and Social Research. 62,279 286.

Master, W. H. and Johnson, V.E. (1966). Human Sexual Response. Boston: Little Brown Company.

Medora, N.P. and Burton N.M. (1979). "Premarital Sexual Norms of an Undergraduate Student Population at a Southern University". Family Perspectives $14,15-20$.

Medora, N. and Woodward, J.C. (1982). "Premarital Sexual Opinions of Undergraduate Students at a Mid-western University". Adolescence 17 (65): 213 224. Spring.

Morton, R.S. (1971), Sex Freedom and Venereal Disease. London: Peter Owens.

Mosher, D.L. and Cross, H.J. (1971), "Sex Guilt and Premarital Sexual Experience of College Students". Journal of Consulting and Clinical Psychology 33, $27-32$.

Niyi, N. (1992), "Interview with Onikepe Oshodi" Poise 2 (45), 20 - 26.

Nwankwo C.A. (1977) "Effectiveness of Hazard Exposure Awareness and Moral Sensitization Techniques I Modifying Adolescents' Premarital and Adult Extra-marital Sexual Attitudes "Ph. D Thesis, Nnamdi Azikiwe University, Awka.

Nworgu, B.G. (1991), Educational Research: Basic Issues and Methodology. Ibadan: Wisdom Pub. Ltd.

Okieh, A.J. (1981) "The Place of Sex Education in Secondary Schools in Nigeria." Health Journal. 3 (1) 27 - 34.

Olayinka, M.S. (1972), Psychology: Growth and Development of Individual Differences" Seminar Paper.

Omoegun, M.S. (1995), the Adolescent and You, Lagos Mobolok Publishing Co. 51 - 52.

Onyemelukwe, G.C. (1991) "Epidemiology and Immunology of HIVIAids." The Workshop on Training of Trainers for Zone B. Nigerian States, Benin city.

Onyemelukwe, I.M. (1993), "Premarital Sexual Practices among the youths and Hindrance to their Adjustment" CASSON Series (1): 29 - 37.

Onyemelukwe, I.M. and Achor, P.E. (1993) Deviant Sex Behaviour among Adolescents: Some Tit-bits for Counselling Purposes" The Counsellor 12 (1).

Oransaye, A.U. and Odiase, G.I. (1983) "Attitudes towards Abortion and Contraception among Nigerian Secondary School girls". International Journal of Gynaecology and Obstetrics. 20 (5), $409-412$.

Osuala, E.C. (1982), Introduction to Research Methodology. Benin city, Ilupeju Press Ltd. P. 180

Onwuamanam, D.O. (1982) "Sexual Activities of School - Going Adolescents in Nigeria" Adolescence. XVII 65

Onwuamanam, D.O. (1983), "Peer and Parental Influence on Sexual Activities of School-Going Adolescence in Nigeria". Adolescence 18, (69): 169 - 179. Spring.

Onwuamanam, D.O. (1988), "Critical Issues in the values of Adolescence Today: Implication for Counselling" The Counsellor 8, 8-16.

Phipps - Yonas, S. (1980), Teenage Motherhood: A Review of the Literature" American Journal of Orthopsychiatry 50(3), $403-431$.

Reiss, I.L. (1967), the Social Context of Premarital Sexual Permissiveness, New York, Holt.

Reiss, I.L. (1964), "The Scaling of Premarital Sexual permissiveness". Journal of Marriage and Family 26: 188 - 198.

Roche, J.P. (1986), "Premarital Sex: Attitudes and Behaviour by Dating State". Adolescence. 21(81) 107 - 121.

Salami, R.A. (1981) Pregnancy among School girls "Nigerian Herald".

Udoh, C.O. (1981), "Is Adolescents Pregnancy Syndrome Real?" Nigerian School Health Journal 3 (1) 21 - 25.

Udry, J.R. (1971), the Social Context of Marriage. New York: J.B. Lippincott Co.

Ukachi, L.A. (1980), The Role of the University in national Development. Nigerian Plateau Publishing Co, Itd.

Wagner, C.A. (1980), "Sexuality of American Adolescents", Adolescence. 15(59) Fall 567 - 580.

Webster, B. (1972), Report of the National Commission on Venereal Disease. DHEW Publication (HSM) Washington D.C.: U.S. G.P.O.

World Health Organization (1964), Chronicle 18, 451

World Health Organization (1964), Chronicle 19, 7

Zelnik, M. and Kantner, J.F. and Ford, K. (1981), Sex and Pregnancy in Adolescence. Beverly Hills, C.A, Sage Publications. 